\title{
Nocardia grenadensis sp. nov., isolated from sand of the Caribbean Sea
}

\author{
Peter Kämpfer, ${ }^{1}$ Nicole Lodders, ${ }^{1}$ Iris Grün-Wollny, ${ }^{2}$ Karin Martin ${ }^{3}$ \\ and Hans-Jürgen Busse ${ }^{4}$
}

\begin{abstract}
Correspondence
Peter Kämpfer peter.kaempfer@agrar.unigiessen.de
\end{abstract}

\author{
${ }^{1}$ Institut für Angewandte Mikrobiologie, Justus-Liebig-Universität Giessen, D-35392 Giessen, \\ Germany \\ ${ }^{2}$ Labor Grün-Wollny, D-35394 Giessen, Germany \\ ${ }^{3}$ Leibniz-Institut für Naturstoff-Forschung und Infektionsbiologie e.V., Hans-Knöll-Institut, D-07745 \\ Jena, Germany \\ ${ }^{4}$ Institut für Bakteriologie, Mykologie und Hygiene, Veterinärmedizinische Universität, A-1210 Wien, \\ Austria
}

A Gram-stain-positive, non-spore-forming bacterium (GW5-5797 ${ }^{\top}$ ) was isolated on soil extract agar from sand collected at a depth of $5 \mathrm{~m}$ in the Caribbean Sea near Grenada. 16S rRNA gene sequence analysis and similarity studies showed that strain GW5-5797 ${ }^{\top}$ belongs to the genus Nocardia, and is most closely related to Nocardia speluncae $\mathrm{N} 2-11^{\top}$ ( $99.2 \%$ similarity) and Nocardia jinanensis $04-5195^{\top}(99.2 \%)$ and more distantly related to Nocardia rhamnosiphila $202 \mathrm{GMO}^{\top}(98.6 \%)$ and other Nocardia species. Strain GW5-5797 ${ }^{\top}$ could be distinguished from all other recognized Nocardia species by sequence similarity values less than $98.5 \%$. The peptidoglycan diamino acid was meso-diaminopimelic acid. Strain GW5-5797 ${ }^{\top}$ exhibited a quinone system with the predominant compounds $\mathrm{MK}-8\left(\mathrm{H}_{4} \omega-\right.$ cyclo $)$ and $\mathrm{MK}-8\left(\mathrm{H}_{2}\right)$. The polar lipid profile of GW5-5797 ${ }^{\top}$ consisted of the major compounds diphosphatidylglycerol, phosphatidylethanolamine and an unidentified glycolipid, moderate amounts of phosphatidylinositol and a phosphatidylinositol mannoside and minor amounts of several lipids including a second phosphatidylinositol mannoside. The polyamine pattern contained the major compound spermine and moderate amounts of spermidine. The major fatty acids were $\mathrm{C}_{16: 0 \text {, }}$ $\mathrm{C}_{18: 1} \omega 9 \mathrm{c}$ and 10-methyl $\mathrm{C}_{18: 0}$. These chemotaxonomic traits are in excellent agreement with those of other Nocardia species. The results of DNA-DNA hybridizations and physiological and biochemical tests allowed genotypic and phenotypic differentiation of strain GW5-5797 ${ }^{\top}$ from the most closely related species, showing $16 \mathrm{~S}$ rRNA gene sequence similarities $>98.5 \%$. Strain GW5 $-5797^{\top}$ therefore merits separate species status, and we propose the name Nocardia grenadensis sp. nov., with the type strain GW5-5797 ${ }^{\top}\left(=\right.$ CCUG $60970^{\top}=$ CIP $\left.110294^{\top}\right)$.
The genus Nocardia now encompasses more than 70 species of mycolic acid-containing actinomycetes with validly published names. Over the last 3 years, the number of Nocardia species has increased to 81 , including the recently described species Nocardia artemisiae (Zhao et al., 2011), N. callitridis (Kaewkla \& Franco, 2010), N. endophytica (Xing et al., 2011), N. iowensis (Lamm et al., 2009), N. jinanensis (Sun et al., 2009), N. mikamii (JannatKhah et al., 2010) and N. niwae (Moser et al., 2011). A

Abbreviations: pNA, $p$-nitroanilide; pNP, $p$-nitrophenyl.

The GenBank/EMBL/DDBJ accession number for the 16S rRNA gene sequence of strain GW5-5797 ${ }^{\top}$ is FR729900.

A supplementary figure is available with the online version of this paper. comprehensive summary of the complex taxonomy of the genus has been given by Goodfellow et al. (1999).

During the characterization of organisms isolated from different soils, strain GW5-5797 ${ }^{\mathrm{T}}$ was recovered on soil extract agar from $1 \mathrm{~g}$ of a sample originating from sand collected at a depth of $5 \mathrm{~m}$ in the Caribbean Sea near Grenada, after a $2 \mathrm{~h}$ extraction in $10 \mathrm{ml}$ of $0.1 \%(\mathrm{v} / \mathrm{v})$ Tween 80 containing $5 \mathrm{mg}$ ampicillin and dilution on mannitol-rifampicin agar [containing $\left(1^{-1}\right)$ : mannitol, $10 \mathrm{~g}$; yeast extract, $7 \mathrm{~g}$; Casamino acids, $2 \mathrm{~g}$; Bacto peptone, $1 \mathrm{~g}$; $\mathrm{NaCl}, 1 \mathrm{~g} ; \mathrm{CaCO}_{3}, 0.2 \mathrm{~g}$; nystatin, $100 \mathrm{mg}$; rifampicin, $5 \mathrm{mg}$ ] and incubation for 6 weeks at $27{ }^{\circ} \mathrm{C}$. The strain was maintained at $25{ }^{\circ} \mathrm{C}$ on DSMZ medium 65 (http://www. dsmz.de/microorganisms/medium/pdf/DSMZ_Medium65. pdf) and, on this agar, showed a yellow to orange substrate 
mycelium that fragmented easily into irregular rod-shaped cells. Orange-white aerial hyphae were formed.

The strain stained Gram-positive using the procedure of Gerhardt et al. (1994), and cell morphology was observed with a Zeiss light microscope at $\times 1000$ using cells grown on medium 65 for 5 days at $25{ }^{\circ} \mathrm{C}$. For PCR amplification of the 16S rRNA gene of strain GW5-5797 ${ }^{\mathrm{T}}$, universal primers 27f and 1492r (Lane, 1991) were used. The $16 \mathrm{~S}$ rRNA gene sequence (1432 bp) was determined as described by Kämpfer et al. (2003). Phylogenetic analysis was performed using the software package MEGA version 4 (Tamura et al., 2007) after multiple alignment of the data by CLUSTAL_X (Thompson et al., 1997). Distances (distance options according to the Kimura-2 model; Kimura, 1980) were calculated and clustering with the neighbour-joining method (Saitou \& Nei, 1987) was performed by using bootstrap values based on 1000 replications (Felsenstein, 1985).

Sequence similarity calculations (on the basis of $1394 \mathrm{nt}$ ) after neighbour-joining analysis (Fig. 1) indicated that the closest relatives of strain GW5-5797 ${ }^{\mathrm{T}}$ were Nocardia speluncae $\mathrm{N} 2-11^{\mathrm{T}}(99.2 \%), N$. jinanensis $04-5195^{\mathrm{T}}(99.2 \%)$ and Nocardia rhamnosiphila $202 \mathrm{GMO}^{\mathrm{T}}(98.6 \%)$. Lower sequence similarities $(<98.5 \%)$ were found with other established species of the genus Nocardia. A neighbourjoining tree for strain GW5-5797 ${ }^{\mathrm{T}}$ and all species of the genus Nocardia with validly published names for which nearly fulllength $16 \mathrm{~S}$ rRNA gene sequences are available is shown in

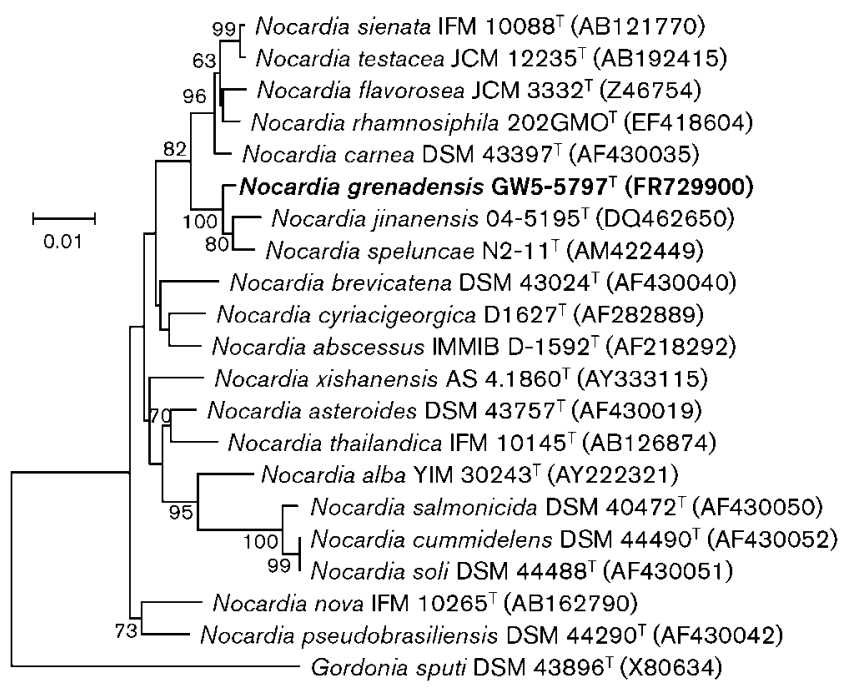

Fig. 1. Neighbour-joining tree reconstructed from the $16 \mathrm{~S}$ rRNA gene sequences of strain GW5-5797 ${ }^{\top}$ and type strains of the genus Nocardia (sequences of type strains taken from the EMBL database; accession numbers given in parentheses). Bootstrap values are percentages based on 1000 replications; only values $>50 \%$ are shown. Bar, 0.01 substitutions per nucleotide position. An extended version of this tree is available as Supplementary Fig. S1.
Supplementary Fig. S1, available in IJSEM Online. Strain GW5-5797 ${ }^{\mathrm{T}}$ still groups with $N$. speluncae and N. jinanensis.

Biomass of GW5-5797 for analysis of the peptidoglycan diamino acid, polar lipids and menaquinones was grown on PYE medium at $25{ }^{\circ} \mathrm{C}$ for $72 \mathrm{~h}(0.3 \%$ peptone from casein, $0.3 \%$ yeast extract, $\mathrm{pH}$ 7.2). Peptidoglycan diamino acid analysis was carried out as described by Schleifer (1985), and meso-diaminopimelic was identified. Analyses of quinones and polar lipids were done as described by Tindall (1990a, b) and Altenburger et al. (1996). HPLC analyses of quinones and polyamines were carried out using the procedure of Stolz et al. (2007). Strain GW5$5797^{\mathrm{T}}$ exhibited a quinone system composed of $65 \%$ MK- $8\left(\mathrm{H}_{4} \omega\right.$-cyclo $)$ and $35 \%$ MK- $8\left(\mathrm{H}_{2}\right)$. The presence of MK- $8\left(\mathrm{H}_{4} \omega\right.$-cyclo $)$ is a characteristic common to all Nocardia species (Goodfellow et al., 1999) analysed so far, including the recently proposed species $N$. callitridis (Kaewkla \& Franco, 2010) and N. mikamii (Jannat-Khah et al., 2010), but significant amounts of MK-8 $\left(\mathrm{H}_{2}\right)$ have rarely been reported in Nocardia species (Rodríguez-Nava et al., 2004; Xu et al., 2005). The polar lipid profile of GW5 $-5797^{\mathrm{T}}$ contained the major compounds diphosphatidylglycerol, phosphatidylethanolamine and an unidentified glycolipid (GL1). Furthermore, moderate amounts of phosphatidylinositol and a phosphatidylinositol mannoside and minor amounts of a second phosphatidylinositol mannoside, two unidentified phospholipids (PL1, PL2) and three unidentified polar lipids (L1-3; not stainable with any of the specific spray reagents molybdenum blue, ninhydrin and $\alpha$-naphthol) were detected (Fig. 2). The identified lipids in the profile of GW5-5797 ${ }^{\mathrm{T}}$ have been shown to be present in several Nocardia strains, as well as

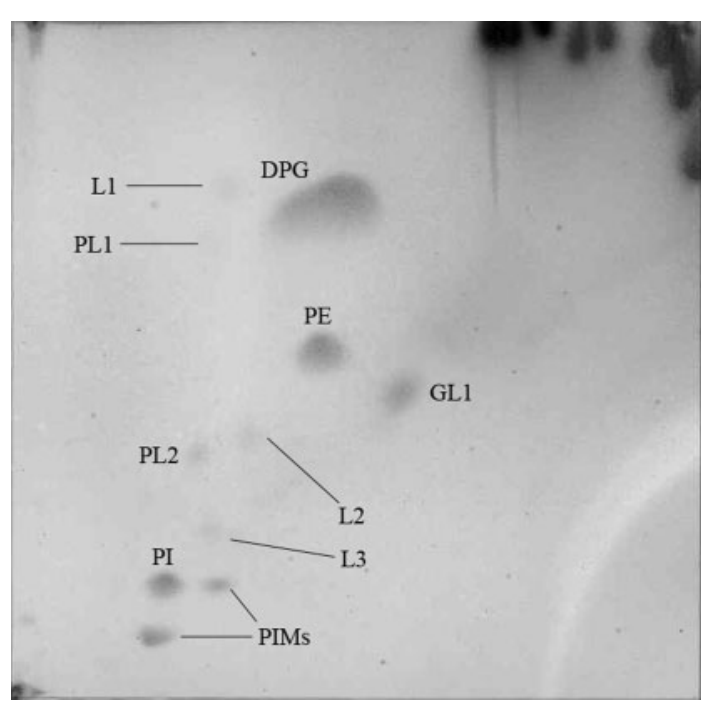

Fig. 2. Total polar lipid profile of strain GW5-5797 ${ }^{\top}$ after staining with molybdatophosphoric acid. DPG, Diphosphatidylglycerol; PE, phosphatidylethanolamine; PI, phosphatidylinositol; PIMs, phosphatidylinositol mannosides; GL1, unidentified glycolipid; L1-3, unidentified polar lipids; PL1-2, unidentified phospholipids. 
an unidentified glycolipid showing chromatographic behaviour similar to that of GL1 (Minnikin et al., 1977). The presence of the aminolipid phosphatidylethanolamine demonstrates that GW5 $-5797^{\mathrm{T}}$ exhibits phospholipid type II (Lechevalier et al., 1977) and thus this polar lipid profile is in accordance with the characteristics of the genus Nocardia. Polyamines were extracted and analysed from biomass grown on PYE medium and harvested at the late exponential growth phase as described by Busse \& Auling (1988) and Altenburger et al. (1997). The polyamine pattern contained the major compound spermine $\left.[0.83 \mu \mathrm{mol} \text { (g dry weight })^{-1}\right]$, moderate amounts of spermidine $[0.24 \mu \mathrm{mol}$ (g dry weight $\left.)^{-1}\right]$ and traces of 1,3-diaminopropane, putrescine and sym-homospermidine $\left.[<0.03 \mu \mathrm{mol} \text { (g dry weight })^{-1}\right]$.

Fatty acid analysis was performed according to Kämpfer \& Kroppenstedt (1996) using the MIDI Sherlock system version 2.11 (TSBA 4.1). The fatty acid profile of strain GW5 $-5797^{\mathrm{T}}$ given in Table 1 was similar to those of closely related species, but also showed some quantitative differences.

Detailed results of the physiological characterization are given in Table 2 and the species description, obtained using methods described previously (Kämpfer et al., 1991). In addition, some tests on the degradation of polymeric substances were performed using standard procedures according to Williams et al. (1983). The results of these tests were read after 7 days of incubation at $28{ }^{\circ} \mathrm{C}$.

DNA-DNA hybridization experiments were performed using the method described by Ziemke et al. (1998), except that, for nick translation, $2 \mu \mathrm{g}$ DNA was labelled during a $3 \mathrm{~h}$ incubation at $15{ }^{\circ} \mathrm{C}$. Hybridization with labelled DNA from the type strains of related Nocardia species gave the following results: $N$. speluncae YEME N2-11 ${ }^{\mathrm{T}}(18.1 \%$, reciprocal analysis $14.1 \%), N$. jinanensis DSM $45048^{\mathrm{T}}$ $(34.4,13.1 \%)$ and N. rhamnosiphila DSM $45147^{\mathrm{T}}$ (15.6, $16.2 \%)$.

On the basis of these results, the novel species Nocardia grenadensis sp. nov. is described to accommodate strain GW5-5797 ${ }^{\mathrm{T}}$.

\section{Description of Nocardia grenadensis sp. nov.}

Nocardia grenadensis (gre.na.den'sis. N.L. fem. adj. grenadensis named after Grenada, from where the type strain was isolated).

Forms a yellow to light-orange vegetative mycelium, fragmenting very rapidly into irregular, rod-shaped elements. Aerial mycelium is yellowish white. Gramstain-positive and oxidase-positive, showing an oxidative metabolism. Good growth occurs on nutrient agar and medium 65 at $25-30{ }^{\circ} \mathrm{C}$. The characteristic diamino acid of the peptidoglycan is meso-diaminopimelic acid. The polyamine pattern contains the major compound spermine and moderate amounts of spermidine. Putrescine, 1,3diaminopropane and sym-homospermidine are present in trace amounts. The quinone system is composed of the
Table 1. Major fatty acids of type strains of species of the genus Nocardia grouped into the same cluster on the basis of 16S rRNA gene sequence similarity studies (see Fig. 1)

Strains: 1 , GW5-5797 ${ }^{\mathrm{T}} ; 2$, N. speluncae YEME N2-11 ${ }^{\mathrm{T}} ; 3$, N. jinanensis DSM $45048^{\mathrm{T}}$; 4, N. rhamnosiphila DSM $45147^{\mathrm{T}}$; 5 , N. carnea DSM $43397^{\mathrm{T}}$. All strains were grown on trypticase soy broth at $28{ }^{\circ} \mathrm{C}$ for 7 days prior to fatty acid analysis. For unsaturated fatty acids, the position of the double bond is located by counting from the methyl $(\omega)$ end of the carbon chain; cis isomers are indicated by the suffix $c$. TBSA, Tuberculostearic acid.

\begin{tabular}{|c|c|c|c|c|c|}
\hline Fatty acid & 1 & 2 & 3 & 4 & 5 \\
\hline \multicolumn{6}{|l|}{ Saturated } \\
\hline $\mathrm{C}_{14: 0}$ & 0.9 & 3.6 & 1.4 & 1.0 & 1.7 \\
\hline $\mathrm{C}_{15: 0}$ & 0.6 & 1.9 & & & 1.0 \\
\hline $\mathrm{C}_{16: 0}$ & 27.2 & 25.9 & 28.6 & 32.9 & 25.2 \\
\hline iso- $\mathrm{C}_{16: 0}$ & 0.8 & & & 1.1 & 1.3 \\
\hline $\mathrm{C}_{17: 0}$ & & 2.7 & 2.9 & 2.3 & 1.3 \\
\hline $\mathrm{C}_{18: 0}$ & 7.0 & 11.0 & 5.6 & 9.7 & 7.5 \\
\hline iso- $\mathrm{C}_{18: 0}$ & & & & & 4.9 \\
\hline $\mathrm{C}_{19: 0}$ & 1.0 & & 0.8 & & \\
\hline $\mathrm{C}_{20: 0}$ & 0.4 & & 1.0 & & 1.6 \\
\hline \multicolumn{6}{|l|}{ Unsaturated } \\
\hline $\mathrm{C}_{16: 1} \omega 9 c$ & 0.6 & & & & \\
\hline $\mathrm{C}_{17: 1} \omega 9 c$ & 0.5 & & & & \\
\hline $\mathrm{C}_{17: 1} \omega 8 c$ & & 1.5 & & & \\
\hline $\mathrm{C}_{18: 1} \omega 9 c$ & 17.2 & 15.8 & 20.2 & 15.9 & 6.1 \\
\hline $\mathrm{C}_{18: 1} \omega 7 c$ & & 1.0 & & & 7.2 \\
\hline $\mathrm{C}_{20: 1} \omega 9 c$ & 3.2 & 2.0 & 1.1 & & \\
\hline \multicolumn{6}{|l|}{ Summed features ${ }^{*}$} \\
\hline Summed feature 3 & 11.2 & 10.2 & 16.7 & 10.8 & 11.2 \\
\hline Summed feature 5 & & 1.8 & & & \\
\hline Summed feature 6 & 1.4 & 2.9 & 0.8 & 1.8 & 3.9 \\
\hline \multicolumn{6}{|l|}{ Others } \\
\hline 10-Methyl $C_{17: 0}$ & & 1.1 & & & \\
\hline 10-Methyl $\mathrm{C}_{18: 0}$ (TBSA) & 20.8 & 18.0 & 19.6 & 23.0 & 21.7 \\
\hline Unknown & 15.0 & 0.9 & 1.0 & 0.4 & 5.2 \\
\hline
\end{tabular}

${ }^{\star}$ Summed features represent groups of two or three fatty acids that cannot be separated by GLC with the MIDI system. Summed feature 3 contained $\mathrm{C}_{16: 1} \omega 7 c$ and/or iso- $\mathrm{C}_{15: 0}$ 2-OH. Summed feature 5 contained $\mathrm{C}_{18: 2} \omega 6,9 c$ and/or anteiso- $\mathrm{C}_{18: 0}$. Summed feature 6 contained $\mathrm{C}_{19: 1} \omega 11 c$ and/or $\mathrm{C}_{19: 1} \omega 9 c$.

major menaquinones MK- $8\left(\mathrm{H}_{4} \omega\right.$-cyclo $)$ and $\mathrm{MK}-8\left(\mathrm{H}_{2}\right)$. The polar lipid profile is composed of the major compounds diphosphatidylglycerol, phosphatidylethanolamine and an unidentified glycolipid, moderate amounts of phosphatidylinositol and a phosphatidylinositol mannoside and minor amounts of a second phosphatidylinositol mannoside, two unidentified phospholipids and three unidentified polar lipids. Major fatty acids are $\mathrm{C}_{16: 0 \text {, }}$ $\mathrm{C}_{18: 1} \omega 9 c$ and 10-methyl $\mathrm{C}_{18: 0}$. Carbon source utilization and hydrolysis of chromogenic substrates (including differentiating characters) are indicated in Table 1. In addition, urea and allantoin are hydrolysed. Adenine, 
Table 2. Physiological properties that distinguish strain GW5$5797^{\top}$ from the type strains of the most closely related Nocardia species

Strains: 1, GW5-5797 ${ }^{\mathrm{T}} ; 2, N$. speluncae YEME N2-11 ${ }^{\mathrm{T}} ; 3, N$. jinanensis DSM 45048 ; 4, N. rhamnosiphila DSM 45147 ${ }^{\mathrm{T}}$; 5 N. carnea DSM $43397^{\mathrm{T}}$. All strains were positive for hydrolysis of aesculin, bis-p-nitrophenyl (pNP) phosphate, pNP phenylphosphonate and L-alanine $p$-nitroanilide (pNA) and utilization of D-glucose, acetate, fumarate, pyruvate and DL-3-hydroxybutyrate. All strains were negative for hydrolysis of $\mathrm{pNP} \beta$-D-glucuronide, $\mathrm{pNP} \beta$-Dgalactopyranoside, pNP $\alpha$-D-glucopyranoside, pNP phosphorylcholine, L-alanine pNA, L-glutamyl $\gamma$-3-carboxy-pNA and L-proline pNA and utilization of $p$-arbutin, gluconate, L-rhamnose, maltitol, Lsorbose, cis- and trans-aconitate, adipate, azelate, citrate, glutarate, itaconate, mesaconate, oxoglutarate, $\beta$-alanine, L-leucine, Lornithine, L-tryptophan and 4-hydroxybenzoate. +, Positive, -, negative; $(+)$, weakly positive.

\begin{tabular}{|c|c|c|c|c|c|}
\hline Test & 1 & 2 & 3 & 4 & 5 \\
\hline \multicolumn{6}{|l|}{ Hydrolysis of: } \\
\hline pNP $\beta$-D-glucopyranoside & - & - & + & + & - \\
\hline pNP $\beta$-D-xylopyranoside & - & - & - & + & - \\
\hline pNP phenylphosphonate & - & - & - & + & - \\
\hline $\begin{array}{l}\text { 2-Deoxythymidine- } 5^{\prime} \text {-pNP } \\
\text { phosphate }\end{array}$ & - & + & - & - & - \\
\hline \multicolumn{6}{|l|}{ Assimilation of: } \\
\hline$N$-Acetyl-D-galactosamine & $(+)$ & - & - & - & - \\
\hline$N$-Acetyl-D-glucosamine & + & + & - & - & - \\
\hline L-Arabinose & + & - & - & - & + \\
\hline Cellobiose & + & - & - & - & - \\
\hline D-Fructose & + & - & - & - & - \\
\hline D-Galactose & + & - & - & - & + \\
\hline D-Mannose & + & - & - & - & - \\
\hline Maltose & + & - & - & - & - \\
\hline Melibiose & + & - & - & + & - \\
\hline D-Ribose & + & + & - & - & - \\
\hline Sucrose & + & - & - & - & - \\
\hline Salicin & + & - & - & - & - \\
\hline Trehalose & + & - & + & + & - \\
\hline D-Xylose & + & - & - & - & - \\
\hline Adonitol & + & - & - & - & - \\
\hline myo-Inositol & + & + & - & - & - \\
\hline D-Mannitol & + & - & - & - & - \\
\hline Putrescine & - & + & - & - & - \\
\hline Propionate & - & + & + & + & + \\
\hline 4-Aminobutyrate & + & - & - & - & + \\
\hline DL-Lactate & - & - & + & - & - \\
\hline L-Malate & + & + & - & + & + \\
\hline Suberate & + & - & - & - & - \\
\hline L-Alanine & + & + & - & - & - \\
\hline L-Aspartate & + & - & - & - & - \\
\hline L-Histidine & + & - & - & - & - \\
\hline L-Phenylalanine & + & - & - & - & - \\
\hline L-Proline & + & + & - & - & - \\
\hline L-Serine & + & - & - & + & - \\
\hline 3-Hydroxybenzoate & + & - & - & + & - \\
\hline Phenylacetate & + & - & - & + & - \\
\hline
\end{tabular}

tyrosine, casein and starch (weakly) are degraded, but xylan, hypoxanthine and xanthine are not.

The type strain is GW5-5797 ${ }^{\mathrm{T}}$ (=CCUG $60970^{\mathrm{T}}=\mathrm{CIP}$ $110294^{\mathrm{T}}$ ), isolated from sand collected at a depth of $5 \mathrm{~m}$ in the Caribbean Sea near Grenada.

\section{References}

Altenburger, P., Kämpfer, P., Makristathis, A., Lubitz, W. \& Busse, H.-J. (1996). Classification of bacteria isolated from a medieval wall painting. J Biotechnol 47, 39-52.

Altenburger, P., Kämpfer, P., Akimov, V. N., Lubitz, W. \& Busse, H.-J. (1997). Polyamine distribution in actinomycetes with group $B$ peptidoglycan and species of the genera Brevibacterium, Corynebacterium and Tsukamurella. Int J Syst Bacteriol 47, 270-277.

Busse, H.-J. \& Auling, G. (1988). Polyamine pattern as a chemotaxonomic marker within the Proteobacteria. Syst Appl Microbiol 11, $1-8$.

Felsenstein, J. (1985). Confidence limits on phylogenies: an approach using the bootstrap. Evolution 39, 783-791.

Gerhardt, P., Murray, R. G. E., Wood, W. A. \& Krieg, N. R. (editors) (1994). Methods for General and Molecular Bacteriology. Washington, DC: American Society for Microbiology.

Goodfellow, M., Isik, K. \& Yates, E. (1999). Actinomycete systematics: an unfinished synthesis. Nova Acta Leopold NF80, 47-82.

Jannat-Khah, D., Kroppenstedt, R. M., Klenk, H.-P., Spröer, C., Schumann, P., Lasker, B. A., Steigerwalt, A. G., Hinrikson, H. P. \& Brown, J. M. (2010). Nocardia mikamii sp. nov., isolated from human pulmonary infections in the USA. Int J Syst Evol Microbiol 60, 22722276.

Kaewkla, O. \& Franco, C. M. M. (2010). Nocardia callitridis sp. nov., an endophytic actinobacterium isolated from a surface-sterilized root of an Australian native pine tree. Int J Syst Evol Microbiol 60, 15321536.

Kämpfer, P. \& Kroppenstedt, R. M. (1996). Numerical analysis of fatty acid patterns of coryneform bacteria and related taxa. Can $J$ Microbiol 42, 989-1005.

Kämpfer, P., Steiof, M. \& Dott, W. (1991). Microbiological characterisation of a fuel-oil contaminated site including numerical identification of heterotrophic water and soil bacteria. Microb Ecol 21, 227-251.

Kämpfer, P., Dreyer, U., Neef, A., Dott, W. \& Busse, H.-J. (2003). Chryseobacterium defluvii sp. nov., isolated from wastewater. Int J Syst Evol Microbiol 53, 93-97.

Kimura, M. (1980). A simple method for estimating evolutionary rates of base substitutions through comparative studies of nucleotide sequences. J Mol Evol 16, 111-120.

Lamm, A. S., Khare, A., Conville, P., Lau, P. C. K., Bergeron, H. \& Rosazza, J. P. N. (2009). Nocardia iowensis sp. nov., an organism rich in biocatalytically important enzymes and nitric oxide synthase. Int $J$ Syst Evol Microbiol 59, 2408-2414.

Lane, D. J. (1991). 16S/23S rRNA sequencing. In Nucleic Acid Techniques in Bacterial Systematics, pp. 115-175. Edited by E. Stackebrandt \& M. Goodfellow. Chichester: Wiley.

Lechevalier, M. P., De Bièvre, C. \& Lechevalier, H. (1977). Chemotaxonomy of aerobic actinomycetes: phospholipid composition. Biochem Syst Ecol 5, 249-260.

Minnikin, D. E., Patel, P. V., Alshamaony, L. \& Goodfellow, M. (1977). Polar lipid composition in the classification of Nocardia and related bacteria. Int J Syst Bacteriol 27, 104-117. 
Moser, B. D., Klenk, H. P., Schumann, P., Pötter, G., Lasker, B. A., Steigerwalt, A. G., Hinrikson, H. P. \& Brown, J. M. (2011). Nocardia niwae sp. nov., isolated from human pulmonary sources. Int $J$ Syst Evol Microbiol 61, 438-442.

Rodríguez-Nava, V., Couble, A., Molinard, C., Sandoval, H., Boiron, P. \& Laurent, F. (2004). Nocardia mexicana sp. nov., a new pathogen isolated from human mycetomas. J Clin Microbiol 42, 4530-4535.

Saitou, N. \& Nei, M. (1987). The neighbor-joining method: a new method for reconstructing phylogenetic trees. Mol Biol Evol 4, 406-425.

Schleifer, K. H. (1985). Analysis of the chemical composition and primary structure of murein. Methods Microbiol 18, 123-156.

Stolz, A., Busse, H.-J. \& Kämpfer, P. (2007). Pseudomonas knackmussii sp. nov. Int J Syst Evol Microbiol 57, 572-576.

Sun, W., Zhang, Y. Q., Huang, Y., Zhang, Y. Q., Yang, Z. Y. \& Liu, Z. H. (2009). Nocardia jinanensis sp. nov., an amicoumacin B-producing actinomycete. Int J Syst Evol Microbiol 59, 417-420.

Tamura, K., Dudley, J., Nei, M. \& Kumar, S. (2007). MEGA4: molecular evolutionary genetics analysis (MEGA) software version 4.0. Mol Biol Evol 24, 1596-1599.

Thompson, J. D., Gibson, T. J., Plewniak, F., Jeanmougin, F. \& Higgins, D. G. (1997). The CLUSTAL_X windows interface: flexible strategies for multiple sequence alignment aided by quality analysis tools. Nucleic Acids Res 25, 4876-4882.
Tindall, B. J. (1990a). A comparative study of the lipid composition of Halobacterium saccharovorum from various sources. Syst Appl Microbiol 13, 128-130.

Tindall, B. J. (1990b). Lipid composition of Halobacterium lacusprofundi. FEMS Microbiol Lett 66, 199-202.

Williams, S. T., Goodfellow, M., Alderson, G., Wellington, E. M. H., Sneath, P. H. A. \& Sackin, M. J. (1983). Numerical classification of Streptomyces and related genera. J Gen Microbiol 129, 17421813.

Xing, K., Qin, S., Fei, S.-M., Lin, Q., Bian, G.-K., Miao, Q., Wang, Y., Cao, C.-L., Tang, S.-K. \& other authors (2011). Nocardia endophytica sp. nov., an endophytic actinomycete isolated from the oil-seed plant Jatropha curcas L. Int J Syst Evol Microbiol 61, 1854-1858.

Xu, P., Li, W.-J., Tang, S.-K., Jiang, Y., Chen, H.-H., Xu, L.-H. \& Jiang, C. L. (2005). Nocardia polyresistens sp. nov. Int J Syst Evol Microbiol 55, 1465-1470.

Zhao, G.-Z., Li, J., Zhu, W.-Y., Klenk, H.-P., Xu, L.-H. \& Li, W.-J. (2011). Nocardia artemisiae sp. nov., an endophytic actinobacterium isolated from a surface-sterilized stem of Artemisia annua L. Int J Syst Evol Microbiol 61, 2933-2937.

Ziemke, F., Höfle, M. G., Lalucat, J. \& Rosselló-Mora, R. (1998). Reclassification of Shewanella putrefaciens Owen's genomic group II as Shewanella baltica sp. nov. Int J Syst Bacteriol 48, 179-186. 